\title{
Enlarging the Negotiation Table with Business Sector Actors: Who, How and with What Effect?
}

\author{
C. Esra Cuhadar \\ Department of Political Science and Public Administration, Bilkent University, \\ 06800 Ankara, Turkey \\ esracg@bilkent.edu.tr
}

Received 9 April 2017; accepted 20 October 2018

\begin{abstract}
This article examines the inclusion of business sector actors in peace and political transition negotiations. Looking across twenty-two cases, this study examines who has been included as business sector representatives in these negotiations and through which inclusion modalities. The study finds that business sector actors were included primarily through consultation modalities in officially mandated meetings running parallel to negotiations, informal consultations, or as part of public consultations. Second most common is direct representation of business sector actors at the negotiation table. Less common is business sector inclusion in high-level track one-anda-half workshops and inclusive commissions. The article then focuses on the impact of business actors on negotiations. Four cases of business inclusion are discussed in detail - Somalia, Kenya, Guatemala and El Salvador - comparing and contrasting supportive and obstructive examples.
\end{abstract}

\section{Keywords}

inclusion in peace negotiations - business participation in negotiations - business actors' resistance to peace processes - inclusive negotiation processes

* Esra Çuhadar is an Associate Professor at the Department of Political Science and Public Administration at Bilkent University in Turkey and a Senior Fellow at the Inclusive Peace and Transition Initiative at the Graduate Institute, Geneva. 
Business/economic sector actors ${ }^{1}$ are included in peace and political transition negotiations quite frequently, and they have the ability to influence negotiation outcomes in addition to other societal actors such as women and civil society. However, scholarly literature on inclusion in peace negotiations has focused mainly on civil society (e.g. Nilsson 2012; Paffenholz 2014), women (e.g. Bell 2015; Paffenholz et al. 2016), and youth (e.g. Grizelj 2017), and neglected analyzing the inclusion of business sector representatives and their effect on the negotiation process. As opposed to the normative frameworks that primarily drive women and youth inclusion (UNSC Resolutions 1325 and 2250 respectively), business sector actors' inclusion in peace negotiations does not rely on normative international frameworks. Yet, even without promotion from international policy circles, we see that economic sector actors constitute one of the most common categories when we examine empirical evidence concerning who was included in peace and political transition negotiations. This is independent of the degree and direction of influence they have over the negotiations. Business sector actors are often included because they have a strong interest in the outcome of the negotiated agreement and its implementation. Many peace agreements signed in the last two decades include provisions regarding socio-economic reforms that concern economic actors, whether they are supportive of or resistant against these reforms brought upon by a peace agreement.

Although there is scholarly writing on the role of economic sector actors in contributing to the root causes of conflicts (e.g. Stewart \& Brown 2007; Levinger 2013; Collier \& Hoeffler 2000), much less is written on how and why they are included (or not) in peace processes in general and peace negotiations in particular, and with what consequences. ${ }^{2}$ The existing literature treats the role of economic sector representatives in peace processes as similar to those of other civil society actors, and focuses on possible economic activities business actors should undertake to support a peace process (Nelson 2000; Killick et al. 2005; Forrer, Fort \& Gilpin 2012). In particular, scholarship has neglected why, how, and when business actors in particular participate in negotiations. This article focuses on the questions of why, how, and when economic sector representatives are included in negotiations and their impact by providing insights from a comparative case study of forty inclusive peace and transition negotiation

1 These terms are used interchangeably in this article for practicality as the article refers to a broad range of economic sector actors.

2 In this article, peace process refers to the broad and long-lasting process of building peace, including pre-negotiation, negotiation, and implementation phases. Peace negotiation is used to refer to the process of negotiating an agreement that ends the conflict. 
cases conducted under the "Broadening Participation" (BP) project, which is currently housed at the Inclusive Peace and Transition Initiative in Geneva. ${ }^{3}$

The article describes business sector actors broadly, mainly driven by the data. Business inclusion is defined as the participation of the representatives of commerce/trade, financial, and industrial sectors in peace and political transition negotiations. Participation of business actors in negotiations is not very different from the inclusion of other societal actors, such as women, in the sense that representatives are sometimes from a more organized and institutional entity (e.g. trade unions, various business and manufacturers associations) and at other times it may be unorganized or un-institutionalized (e.g. small business owners, eminent business personalities in the country). The article takes both organized and unorganized forms of economic sector inclusion into account and presents findings from the BP research in terms of what kind of actors were included in the cases examined and why, how, and with what effect these actors participated in peace negotiations.

\section{Research Framework and Data}

This article relies on case studies conducted under the "Broadening Participation in Peace and Transition Negotiations" (BP) project. The project adopted the structured-focused comparative case study method and process tracing approach to examine forty peace and political transition negotiation cases from around the world. The focus of the study was to identify who was included, when, and how inclusion took place in these negotiations. The project first formulated a case study guideline based on the themes and categories from the preliminary work conducted on the topic by Paffenholz (2014). In her earlier exploratory work, Paffenholz identified nine different modalities of inclusion based on literature review, interviews, and group discussions with mediators, negotiators, and included actors. She argued that there remains an excessive focus on the negotiation table as the locus of a peace process. Instead, inclusion takes place in all phases of the peace process at and alongside the negotiation

3 The project ran between $2013-2015$ at the Graduate Institute for International Studies and Development in Geneva led by Thania Paffenholz, and at Bilkent University in collaboration with Esra Cuhadar. Eileen Babbitt from Tufts University contributed to the case study phase of the project. The project gathered information on modalities of broader participation in forty negotiation cases. It was funded by the Foreign Ministries of Switzerland, Norway, Finland, Turkey, and Germany. For more information see: http://graduateinstitute.ch/home/ research/centresandprogrammes/ccdp/ccdp-research/clusters-and-projects-1/participatory -peace-processes-an/broadening-participation-in-trac.html. 
table and through a variety of modalities. Direct representation at the table is only one of the modalities of inclusion. The modalities previously identified by Paffenholz (2014) were crystallized into seven modalities as detailed in this article, and the relationship between these modalities and business inclusion specifically are detailed below (for general remarks about modalities, please refer to Paffenholz (2019)).

1. Direct representation at the negotiation table: An example of business inclusion within this modality is from Afghanistan's Loya Jirga. It was convened following the Bonn conference in June 2002 to choose a new Afghan Transitional Authority (ATA) in order to rule the country for the next 18 months. During this time, the new transitional government would formulate a new constitution and prepare national general elections. The Loya Jirga (Grand Council) gathered 15,000 delegates and 1,500 final participants, which included 160 seats reserved for women, representatives from various districts and regions of Afghanistan including the "ulema" (religious leaders), intellectuals, religious minorities, and, importantly, tradesmen.

2. Observer status: This modality was not used in any of the cases to include business actors.

3. Consultation: This modality was the most frequently utilized one to include economic actors, both at the formal and informal levels. Examples of business inclusion in officially mandated civil society forums were the case in Guatemala (CEPAZ - Business Peace Commission) and Afghanistan; whereas informal consultations with business actors took place in several cases such as during the Kenya's post-election violence negotiations. Business actors also participated in, and sometimes even organized and initiated, public consultations: for example, the public consultation process in Turkey for a new constitution drafting, called the Constitution Platform, was organized by the largest business organization (товв) in the country.

4. Inclusive Commission: Business actors participated in inclusive commissions, as demonstrated in the cases of both Mali and Papua New Guinea. Mali's Economic and Social Council played a role in the country's political transition, and the inclusive Constitutional Commission contributed to Papua New Guinea's Bougainville peace negotiations between 1997 and 2005. In both cases, trade unions and other business representatives were involved.

5. High-level problem-solving workshops (Track 1.5): Business actors were included in these types of workshops, such as in Fiji (in the process called 
Dialogue Fiji) and in track 1.5 workshops between Georgian and Abkhaz representatives.

6. Public decision-making (i.e. referendum): In some cases, business actors took an active role in referenda either by supporting an agreement or rallying against it. While in Togo they played a supportive role, in Guatemala large business associations rallied against the ratification of the certain parts of the peace agreement in the referendum.

7. Mass action: Like referendum, sometimes business actors supported mass action to support peace or democratic political transition and at other times they rallied against peace agreements.

For the BP project, the framework and the case study guideline were developed based on these modalities as well as additional themes for cross case inquiry. Categories of inquiry included the following for each case: conflict context (brief history of the conflict and the peace process), identification of modalities of inclusion, actors involved in each modality of inclusion, duration of inclusion modality, rationale for inclusion, initiation of the inclusion, selection procedures, transfer mechanisms between the modality and official negotiations, decision-making procedures within the modality, and the role of the mediator. These themes were explored for each case systematically, and this framework was applied to forty negotiation cases spanning between 1990 and 2013. The unit of analysis has been the negotiation process; thus, one conflict has in some circumstances produced multiple cases. All negotiation cases selected for the study had some type of broader inclusion of those other than the representatives of main negotiators. Negotiation cases include peace negotiations between a state and an armed group, between two states, negotiations for political reforms and political transitions, or negotiations involving both peace and political transition. ${ }^{4}$

The research analyzed the role of all relevant actors that participated in the different inclusion modalities next to the main parties to the conflict; in other words, there has not been emphasis on any actor from the beginning (e.g., women or civil society), but whichever actor was involved in the process was identified and analyzed. Cases were selected based on geographical representation and variation in inclusion modalities.

Initial case studies were written by a group of around 30 graduate students recruited from three graduate programs at Fletcher School of Law and Diplomacy, Graduate Institute of International Studies and Development in

4 The list of all cases examined under the project can be found at: https://www.inclusivepeace .org/content/broadening-participation. 
Geneva, and Bilkent University in Ankara. These students were trained in the case study framework and guideline. Completed case studies were then first subjected to internal assessment by the senior research team, and subsequently subjected to an external review process by area and process experts identified for each conflict. After the completion of the case study analysis phase, each case was then coded by the core research team (including the author of this article) for its content following the research framework with the help of the computer software called NVivo. The coding process allowed us to do a frequency analysis.

Business actors were identified as one of the societal actors included in negotiation processes as a result of the coding. They were included in peace and political transition negotiations in twenty-two out of forty cases $(55 \%)$. This establishes business actors as the fourth ranking actor after organized civil society, women, and opposition political parties for inclusion in these types of negotiations. While business is one of the included actors, the type of business actors and the mechanisms through which business is included vary widely among cases. Findings discussed in this article are based on the coding of business inclusion in these twenty-two cases. A second round of coding was conducted by the author with regard to what kind of business actors were included, in which modalities, why, and with what effect.

In four out of twenty-two cases, business actors were involved in negotiation through the mass action modality. In the other eighteen cases out of forty, business actors were included through other six modalities discussed above. Consultations with business actors (either officially mandated, informal, or public) and direct representation of business actors at the table are the two most commonly used modalities (see Table 1 below). The third most frequent modality is participation of business representatives in high-level problemsolving (Track 1.5) workshops, which is followed by participation in inclusive commissions. We did not identify any case where business actors were granted an observer status in negotiations.

The four cases in which business was involved in the peace or political transition process through mass action were Egypt, Mexico, Sri Lanka, and Togo. ${ }^{5}$ In these cases, business support for mass action was not necessarily pro-peace. In Egypt and Togo, business actors supported protests and demonstrations

5 It should be noted that there may be business actors working for peace in these cases at the Track 2 or 3 levels as well. However, our data is only concerned with business activities as classified in the modalities and in relation to the negotiation process only. For instance, there may be some business activity at the grassroots level supporting peace. Yet, such civil society activities are not included in the study if they are not targeting or in the framework of the negotiation process. 
that sought the ousting of authoritarian regimes. In Togo, they supported the anti-regime protests because the current regime's policies were hurting the country economically and were against business interests. Therefore, echoing what Killick et al. (2005) suggest, business became involved in mass action seeking regime change when their interests were hurt. However, in Sri Lanka, business support for mass action was in the form of supporting the status quo that favored the Sinhalese dominance in politics and society and was therefore against the peace process with Tamils. Sinhalese nationalist business supported anti-peace rallies in the country, together with the Sinhalese civil society and the Buddhist monks, during the peace negotiations between 2000 and 2004.

In some cases, business actors are included in more than one occasion throughout the peace process within multiple and different inclusion modalities. For instance, during the political transition in Mali between 1990 and 1992, business actors first directly took part in the negotiations at the National Dialogue Conference, and then played a role within a subsequent inclusive commission, the Economic and Social Council, which was another inclusion modality created during the implementation phase. It can also be seen that in different inclusion modalities, different types of business actors are included in the same conflict context. For instance, in Afghanistan different groups of business actors were included in the Loya Jirga (direct representation), in the civil society consultative forum during the Bonn negotiations (official consultations), and in public consultations held for the constitution drafting process (another consultative process). Traders were in Loya Jirga, Afghan businessmen from Dubai were in the parallel consultative forum, and various other businesspeople were consulted in public consultations.

In most cases, business was included with other civil society actors and not alone (discussed in further detail in the next section). Table 1 below summarizes which modality of inclusion was used in each case. Business inclusion as part of a broader civil society umbrella takes place under the following modalities: direct representation of business representatives at the table (e.g. DRC), within an officially mandated consultative civil society forum (e.g. Afghanistan), in public consultations (e.g. Guatemala), as part of an inclusive commission (e.g. Eritrea), and as part of a track one and a half diplomacy initiative (e.g. Fiji, Georgia-Abkhazia). ${ }^{6}$

6 For the full title and duration of the negotiation case study, please refer to Table 1. 


\begin{tabular}{|c|c|}
\hline Case & Modality \\
\hline Afghanistan (Bonn negotiations, 2001-2005) & $\begin{array}{l}\text { Direct Representation; Officially } \\
\text { Mandated Consultative Body; } \\
\text { Public Consultations }\end{array}$ \\
\hline Colombia (1998-2002) & Public Consultations \\
\hline DRC (Inter-Congolese negotiations, 1999-2003) & Direct Representation \\
\hline Egypt (2011-2013) & Mass Action \\
\hline El Salvador (Negotiations with FMLN, 1990-1994) & Direct Representation \\
\hline Eritrea (Constitution-making process, $1993^{-1997)}$ & Inclusive Commission \\
\hline $\begin{array}{l}\text { Fiji (Political transition and constitution-making process, } \\
2006-2013 \text { ) }\end{array}$ & Track 1.5 High Level Psw \\
\hline Georgia-Abkhazia (UN mediated peace negotiations, & Official Consultation \\
\hline 1997-2007) & High Level Psw \\
\hline Guatemala (1989-1999) & $\begin{array}{l}\text { Official Consultation; Public } \\
\text { Consultation Body }\end{array}$ \\
\hline Kenya (post-election violence negotiations, 2008-2013) & Informal Consultations \\
\hline Liberia (Comprehensive Peace Agreement, 2003-2011) & Direct Representation \\
\hline Mali (political transition negotiations, 1990-1992) & Inclusive Commission \\
\hline $\begin{array}{l}\text { Mexico-Chiapas (ceasefire and peace negotiations, } \\
\text { 1994-1997) }\end{array}$ & Mass Action \\
\hline Moldova-Transdniestria (1992-2005) & High Level Psw \\
\hline $\begin{array}{l}\text { Northern Mali (Tuareg conflict peace negotiations, } \\
\text { 1990-1996) }\end{array}$ & Public Consultations \\
\hline $\begin{array}{l}\text { Papua New Guinea - Bougainville peace negotiations } \\
(1997-2005)\end{array}$ & Inclusive Commission \\
\hline $\begin{array}{l}\text { Somalia National Reconciliation Conference - Djibouti } \\
\text { process (1999-2002) }\end{array}$ & Direct Representation \\
\hline Somalia National Peace Conference, Eldoret/Mbagathi & Direct Representation; Informal \\
\hline Kenyan mediation $(2001-2005)$ & Consultations \\
\hline $\begin{array}{l}\text { South Africa (Negotiations for the dismantlement of } \\
\text { the Apartheid Regime and the Political Transition to } \\
\text { Democracy, 1990-1997) }\end{array}$ & Inclusive Commission \\
\hline $\begin{array}{l}\text { Sri Lanka (ceasefire agreement and negotiations, } \\
2000-2004)\end{array}$ & Mass Action \\
\hline Togo (democratic transition negotiations, 1990-2006) & Mass Action \\
\hline $\begin{array}{l}\text { Turkey (Kurdish conflict ceasefire and negotiations, } \\
2009-2015 \text { ) }\end{array}$ & $\begin{array}{l}\text { Public Consultations; } \\
\text { Constitution Platform }\end{array}$ \\
\hline
\end{tabular}




\section{Types of Business Actors Included}

As far as the types of economic sector actors included, one variation is found to be between representatives from organized and unorganized sectors. Organized participation in negotiations includes representatives of trade unions (e.g. in Mali and Papua New Guinea Bougainville negotiations), entrepreneurs' associations (e.g. Kenya), and organizations established by and for business people [e.g. Somali Business Council in Somalia negotiations, Coordinating Committee of Commercial, Industrial, and Financial Associations (CACIF) in Guatemala, and Asociacion Nacional de la Empresa Privada/National Association for Private Business (ANEP) in El Salvador]. However, organized entities were not the only type of economic sector actor that participated in negotiations. There are also cases where the included actors from this sector were not drawn from a formal organization, such as eminent business personalities. This was the case in Liberia negotiations where Gyude Bryant, a prominent businessman, was selected to chair the interim transitional government. Though he was a politician, his business personality was better known, and he was brought to this position because of what that role in particular symbolized in the society. He was seen as neutral by all parties and also had been an outspoken critic of Samuel Doe and Charles Taylor.

Finally, somewhere between representation of unorganized businesspeople and of formal organizations, there are ad hoc entities established specifically during the negotiations to represent business. An example of such an entity is Business Peace Commission (CEPAZ) in Guatemala, which is a body representing commercial, financial, and industrial sectors within the consultative body of Civil Society Assembly.

\section{Forms of Business Inclusion: Stand-alone Inclusion vs. within Broader Civil Society}

Another variation within business inclusion is concerned with whether business is included as a stand-alone group in the negotiations or as part of a broad civil society representation. Cases where business actors were included independently were Somalia (2001-2005), Kenya (in 2008), Mali (1990-1992), Guatemala (1989-1999), and El Salvador (1990-1994). In Kenya (Kenya Manufacturers Association), Somalia (Somali Business Council), and Guatemala business actors were included in negotiations through consultations. In Mali, business actors were included through a commission (see below for details). El Salvador is not only a standalone business inclusion example, but is unique in terms of the direct participation of a group of business sector representatives in the negotiations and utmost impact. Business played a critical role by shaping the peace process design and participated in the 
negotiation table directly as part of President Cristiani's negotiation team. FUSADES, which was a think tank founded by wealthy businessmen in the country dwelling on socio-economic issues, and ANEP (a large business association) were included in the negotiation delegation by the government and made direct input into the agreement. They also played a central role in the implementation phase.

The more common form of business inclusion is within a broad civil society umbrella. This is especially the case when there is a parallel civil society forum established to run simultaneously with official negotiations. Business actors take their place in such forums in addition to NGO representatives, religious leaders, women's organizations, academics etc. Examples of this kind of inclusion can be seen in Afghanistan during the Bonn negotiations, during the inter-Congolese negotiations in the Democratic Republic of Congo in 1999, during the negotiations for reforms and new constitution for democratic transition in Fiji after 2006, the Georgia-Abkhazia negotiations after 1997, MoldovaTransnistria negotiations, negotiations in Somalia between 1999 and 2001, and in Turkey during the process for the resolution of the Kurdish issue between 2013 and 2015 .

The cases in which business actors were included as stand-alone actors deserve more scrutiny, as this singling out elevates their potential influence in the negotiations. The next section of this article focuses on these stand-alone business inclusion cases by first looking into their conditions. Second, the article delves into deeper analysis of the four of the stand-alone inclusion cases: El Salvador, Guatemala, Kenya, and Somalia.

The first condition in which business is included as a stand-alone actor is when there is an inclusive commission established specifically to deal with economic and social affairs. An example of this condition can be seen in negotiations in Mali between 1990 and 1992. The Economic and Social Council (Conseil Economique, Social, et Culturel) was established with a constitutional order as a post-agreement body in Mali in which trade union and other economic sector representatives played a key role. Between 1990 and 1992, Mali transitioned from an authoritarian regime towards a democratic one through a negotiated process, initiated by protests and uprisings by students and civil society. Following the demonstrations in Bamako, a National Dialogue Conference (July 29 to August 12, 1991) was designed to negotiate the end of Mali's authoritarian regime. In 1992 the new regime was officially adopted, together with a new constitution that was accepted through referendum. The first democratic presidential election that followed the referendum introduced a new era of multi-party democratic rule to Mali. First negotiated and adopted during the National Dialogue Conference, the Conseil was authorized in the 
new 1991 Constitution to oversee social, economic, and cultural issues touching upon the Malian people and civil society members. The membership to the Conseil was required to be representative. Its mandate was to collect and draft guidelines and proposals, with the participation of all its members, to bring to the attention of the President of the Republic, the Government, and the National Assembly, about the expectations, needs, and problems of the civil society. In this sense, it made sure that the inclusive negotiation process undertaken in the prior National Dialogue Conference was followed with another inclusive commission to implement social and economic transition in the country; in other words, establishing continuity was established between the negotiation and implementation phases. Trade unions especially took an active part in both the negotiation and implementation stages.

The second condition in which we see stand-alone inclusion of the business sector is where the economic elites are key actors in the conflict or the political landscape of the country. In these cases, the economic elite can either become a potential spoiler or contribute to the resolution of the conflict. In the former case, a potential powerful spoiler in El Salvador was successfully accommodated in the negotiations and eventually played a supportive role. In Guatemala, however, the business elite organized under CACIF played an obstructive role throughout the negotiations and especially during the implementation. In the latter case, in both Kenya and Somalia, business actors were supportive because they had a vested interest in creating a peaceful environment where business could flourish. We probe into these four cases in detail in the next section and explore the rationale for business actors' resisting (Guatemala), compromising (El Salvador), or supporting (Kenya and Somalia) behaviors in inclusive peace negotiations.

\section{Understanding Business Sector's Resistance, Compromise and Support to Inclusive Peace Negotiations}

Much has been written about the role of economic factors as root causes and motivators of civil conflicts. According to the economist Frances Stewart (Stewart \& Brown 2007, cited in Levinger 2013), three types of economic factors provoke civil conflicts: group inequality such as exclusion and extraction, private motivation or greed, and failure of the social contract. Collier (Collier 2000; Collier \& Hoeffler 2000; Collier \& Hoeffler 2002) highlighted "greed" for resources as the main motivator of conflicts. Resource bounty is a risk factor for social conflict, not only on the side of rebel groups but also on the side of governments. 
Exclusion has been established as another main cause of civil conflicts in numerous studies, and its importance was recently reinforced by a joint study of the UN and World Bank (2018) titled 'Pathways for Peace: Inclusive Approaches to Preventing Violent Conflict.' One of the most influential studies on the topic has been conducted by Acemoglu and Robinson (2013), where they highlight the negative economic consequences of economic and political institutions based on extraction and exclusion. The outcomes of extractive economic and political institutions are not limited to poverty, economic failure, and systematic deepening of structural inequalities; as Galtung (1969) also pointed out, structural inequalities are motivators of collective grievances and social conflicts. A common characteristic of conflict-ridden societies is the entrenchment of extractive institutions, which are discernible through characteristics like cronyism, corruption, nepotism, and exclusion of certain social groups from wealth by concentrating power in the hands of a few (Acemoglu \& Robinson 2013: 68). Extractive systems extract income and wealth from one subset of society, which can overlap with a favored ethnic, religious, racial, caste identity, to benefit a different subset (2013: 70). It is the decisions of political actors, be it historical colonial legacy or present-day dictators, that create extractive or inclusive institutions both economically and politically.

These political-economic dynamics are pervasive in almost any country suffering from civil conflict, and can also help us understand why representatives of key economic actors are often included or resist inclusion in peace negotiations. Their role in creating and maintaining the root causes of conflicts, such as the maintenance of extractive economic institutions as discussed, is one of the reasons why they are also key actors that need to be taken into consideration in a negotiation process. Economic elites that are part of an extractive political and economic system in a country will have a vested interest in the outcome of the negotiation process, either by opposing the negotiation process completely or trying to manipulate the negotiations by being included. Sometimes economic elites are not only motivated by the continuation of their privileged economic and political status, but also by their distinct and potentially privileged social identity (i.e. an ethnic or religious identity). Social identity factors further complicate a conflict, because in this case an extractive economic system is often coupled with "group favoritism" privileging a particular identity group politically and culturally. In such cases, these actors may see the peace process that pushes the country towards a more inclusive society as a threat to their existence. This may result in their sabotaging the peace process or preventing the inclusion and implementation of economically and politically inclusive elements of a peace agreement. 
Political institutions that determine the fate of economic and political life in a country are often decided in a negotiation process. Comprehensive peace agreements to resolve conflicts do not only include cease-fire and security arrangements between the combatants, but also design the political and economic institutions in a country that shape the post-conflict era. Resistance from economic elites to the transformation from extractive to inclusive political and economic institutions is one of the reasons why these actors take an obstructive stance in peace processes. Numerous examples can be given from the BP case studies that resemble the obstructive behavior of economic actors in peace processes. These include negotiation processes in Colombia, El Salvador, Guatemala, Mexico, Fiji, Solomon Islands, Kyrgyzstan, DRC, and Burundi.

In Guatemala and El Salvador, the economic context is similar. There is a privileged economic and political elite that is threatened by the transformation towards a more inclusive system integrating marginalized and excluded segments of the society. Yet, these two cases differ in terms of modalities of business inclusion and its effects. In Guatemala, business sector resisted inclusive negotiations as well as the implementation of the inclusion related content of the peace agreement. In El Salvador, while the traditional landowner elite was resistant to the peace process, another segment of the business sector adopted a compromise strategy to keep their interests in place. They shifted from an obstructive to a supportive role and, instead of resisting and spoiling the peace agreement, they directly participated in the negotiations, compromised, and had significant input that shaped the peace agreement in their favor.

\section{Guatemala: Business Actors' Resistance to Inclusive Negotiations}

Guatemala is a prominent case to further elaborate the resistance of business to an inclusive negotiation process, especially concerning the actions of the most influential entrepreneur association in the country known as the Coordinating Committee of Commercial, Industrial, and Financial Associations (CACIF). Guatemalan peace negotiations, which were initiated in 1989 between the government and the armed group URNG, ended the decades long civil war in the country and successfully resulted in a peace agreement in 1996. Negotiations to end this civil war were conducted in an inclusive manner. One of the inclusive mechanisms established was the Civil Society Assembly (ASC) in 1994 in order to allow the participation of diverse sectors of organized civil society in the negotiations. The ASC was a representative, elected body including political parties, religious groups, unions, academic institutions, small and medium enterprises, journalists, development NGOs, women, Mayan communities 
(indigenous), and human rights organizations (Prado 1996: 30). The ASC was highly influential in the negotiations, as they prepared consensus documents among these civil society actors on various themes covered in negotiations. These documents were to a great extent included in the negotiated agreement (Salvesen 2002: 29).

However, CACIF boycotted participating in this initiative even though they were invited. They also took a stance that was against the peace accord, especially concerning the provisions related to socio-economic reforms, human rights reforms aiming the inclusion of indigenous people, and the trial of human rights violations. Their boycott, or self-exclusion, from the participatory negotiation process continued later with their strong opposition to the implementation of constitutional reforms in these areas during the referendum held in 1999. A widespread 'no' campaign was launched by the political and economic elites who were afraid that the new constitutional reform would bring preferential treatment to the indigenous populations. The 'no' campaign benefited from considerable levels of funding from these business circles and was mounted by politically experienced actors with substantial networks of supporters in rural and urban areas who coherently expressed the fears of the oligarchic sectors including CACIF, Centro para la Defensa de la Constitución (CEDECON), the Pro-Fatherland League, the Association of Dignitaries of the Nation, the Association of Military Veterans of Guatemala (AVEMILGUA), parts of the military elite, and the Evangelical Church. As a result, the referendum on constitutional reforms in 1999 failed, and thus the implementation of the peace accord regarding indigenous rights, the role of the military in a democratic society, democratization of the legislature, and independent judiciary failed (Salvesen 2002: 6).

CACIF, together with the military elite, saw the peace accord as a necessary step only relevant for the demobilization of the armed group, URNG, and for entry and acceptance into a liberal and economically globalized world (Swisspeace 2016). With the support of the political power, Congress and Executive, the corporate sector has since ensured representation, with voice and vote, in at least 58 boards, commissions, and committees of different ranks in state institutions that allowed them to shape the system of rules and regulations that govern a multitude of transactions and decisions, in addition to accessing information in an urgent and privileged manner (Swisspeace 2016). Laws, agreements, and regulations approved by the Congress, the Presidency of the Republic or the Ministries, legalized the participation of the CACIF and the business chambers in the decisions in which the public policies of the country were designed. 
CACIF, strengthened by political institutions, was a highly influential, yet obstructive, business actor in the negotiations and chose unswerving resistance to inclusive institutions throughout the implementation phase. The economic class that controlled the extractive economic institutions, and also had a strong base in politics through establishment parties and the military, rejected participation in the inclusion modalities established during the negotiations. They not only chose to stay outside, but also resisted and lobbied against the implementation of the peace agreement, especially regarding the provisions of the agreement restricting their unconstrained exercise of economic and political power. In the Guatemala negotiations, two major attempts to open the space for broader societal inclusion (i.e. Civil Society Assembly and the Grand National Dialogue) by giving voice to the wide segments of the civil society and other excluded actors were hampered. The pro-status quo elites had the economic and political incentives and power to resist and sabotage the inclusive aspects of the agreements. The referendum over the constitution was a central element in giving voice to people over their future and could contribute to inclusion agenda of the agreements. Yet, due to the resistance of the economic elite, together with other pro-status quo actors, the agreement that could finally address the root causes of the conflict failed at least partially. ${ }^{7}$

\section{El Salvador: Business Actors' Compromise with Inclusive Negotiations}

El Salvador, on the other hand, is a unique case where we see both resistance and support for an inclusive process by business actors simultaneously. This is a case where we also see business actors having the utmost influence on the negotiations. Direct representation of business actors within the government negotiation delegation was certainly a factor in elevating the effect of business on negotiations in El Salvador. The business sector was active in the campaigning stage prior to Alfredo Cristiani's election and before the negotiations commenced by providing economic analysis of the conflict's impact, throughout the negotiation process as part of the negotiating team, and after the signing of the agreement in the implementation phase in aiding FMLN ex-combatants' integration. In the implementation phase, the private sector played a role in pushing for military and judicial reforms, but prevented labor unions from implementing concessions on labor issues which they had also fought

7 Information on the Guatemala case is partially based on the case study prepared for the BP project. 
against in negotiations. Ironically, despite the magnitude of their influence and support to the negotiation process, they were not seen as impartial but rather too closely connected with the government especially by those parts of the society that were in favor of more profound socio-economic reforms.

The deadly armed conflict in El Salvador between the leftist armed group FMLN and the government forces lasted from 1980 until the signing of the Chapultepec peace agreement in $1992 .{ }^{8}$ Negotiations between 1989 and 1992 resulted in the 1994 elections in which FM LN also participated. When Cristiani was elected in June 1989, the newly emerging moderate business sector backed him and his efforts to end the armed conflict through negotiations and implement economic reforms. Christiani's ARENA party maintained important ties to this business community. FUSADES (Fundacion Salvadoreña para el Desarrollo Economico y Social /Salvadorian Foundation for Economic and Social Development), which was founded in 1983 by wealthy businessmen. In addition to fusades, AneP (Asociacion Nacional de la Empresa Privada / National Association for Private Business), a large business association, and ARena (Alianza Republicana Nacionalista/Nationalist Republican Alliance) the pro-business governing party of President Cristiani, were direct participants in the negotiations on the side of government delegation.

What shifted the attitude of business actors towards supporting peace negotiations in El Salvador, contrary to the opposing stance they had taken during the previous negotiation attempts? Rettberg (2006) argues that a shift occurred internally in the El Salvador business sector, which changed its character and moved it towards finance and agro-business and away from traditional land elites linked to land and agriculture. In El Salvador, a division existed between the traditional agrarian economic elite in favor of maintaining the status quo to continue their privileged status and the modernizing business elite that was interested in ending the conflict through a negotiated agreement. This new business elite saw that they would benefit from more opportunities for business in the country and opening up to the world. Rettberg attributes much of this shift in El Salvador to the USAID funded FUSADES, which provided credit lines to support activities in new sectors of the Salvadorian economy. Moreover, this institution provided research regarding the costs of conflict and helped reframe the conflict from an economic perspective. As President Cristiani ran on the double platform of economic reform and ending the internal conflict, the business community supported him and did not obstruct his

8 Information used for this case description is based on the El Salvador study in the BP project database. 
attempts to initiate dialogue with the FMLN. When the talks were convened with the FMLN shortly after Christiani system's inauguration, the loyalty of the business sector was rewarded with access to decision-making processes, and hence this sector's interests were safeguarded during the process.

The historical conditions in El Salvador were similar to that of Guatemala: an extractive/non-inclusive economic and political system where power was mainly held by a sub-set of the society. Since its independence, El Salvador has been marked by great socio-economic inequality and rule of a small oligarchy, known popularly as "las catorce," "the fourteen" referring to fourteen rich and powerful aristocratic families (Rettberg 2006). After World War II and up until the 1970's, the country was uninterruptedly ruled by an alliance of these families and their relatives, together with military forces. These dynamics contributed to the root cause of the conflict and led to the formation of both leftist/ Marxist social movements and armed opposition groups, contesting the power of the ruling right-wing elite. Yet, unlike in Guatemala, this ruling elite came to support the peace process and the following reforms, after being accommodated by the political elite during the negotiations to keep their economic interests intact.

The strong involvement of the business sector in the negotiations brought sustainability to the completion of the peace agreement and support during its implementation. However, their direct alignment with the government and lopsided representation in the negotiations prioritized the interests of this sub-set of society, together with the priorities of the ARENA party, and allowed the fundamental socio-economic inequalities and structures that had initially led to the conflict to remain intact. Various sectors of civil society and leftist groups were not satisfied with the outcome of the peace agreement in terms of tackling the social and economic inequalities in El Salvador. Thus, although the participation of the business sector was important politically in order to include business as a partner for solution instead of a spoiler, their privileged position in accessing power and resources was a clear continuation of the inequality that was persistent in El Salvador.

\section{Somalia and Kenya: Business Sector Supporting Inclusive Negotiations}

The opposite of the situation in Guatemala, and to a lesser degree in El Salvador, is one where economic actors are supportive of inclusive negotiations such as in Kenya and Somalia. Unlike economic actors that benefit from the continuation of the extractive systems privileging them over other societal groups, conflict and ongoing violence are extremely devastating for the interests of 
business actors. An inclusive system and well-functioning political and economic institutions are beneficial to the flourishing of business interests. In such circumstances, we may expect economic actors to be more supportive of negotiations and demand their inclusion in negotiations to give support for its success.

Business actors may turn into a supportive key actor if they see that negotiations can end an economically damaging situation, or if they come to see that peace can benefit them economically. This was the situation in peace negotiations in Somalia (2001-2005), in the political negotiations after the postelection violence in Kenya (2008), and in El Salvador between 1990 and 1994 for at least some of the business elite: all through different modalities and with different outcomes. While the inclusion of business in negotiations did not have much effect in the Somalia case, it had a positive impact in Kenya and El Salvador cases. While the effect in Kenya was indirect through consultations, the effect in El Salvador was more centralized and direct as business actors were part of President's negotiation delegation and were closely affiliated with the government.

Even though business actors had the intention to support the peace negotiations in Somalia and Kenya, and they were both included via consultations, why were business actors in Kenya more successful in influencing the negotiations than in Somalia?

In Somalia, Somali businesspeople were included in the Somalia National Peace Conference negotiations between 2002 and 2004 through semi-official consultations with the Somali Business Council. ${ }^{9}$ The Somali Business Council was a Dubai-based organization of Somali entrepreneurs and business owners, including representatives from the different territories and clans of the country. Three consultations occurred during the negotiation period in Dubai, Kenya, and Djibouti (CRD \& wSP International 2004). These consultations were primarily facilitated by the Center for Research and Dialogue (CRD) based in South-Central Somalia, with financial support from the United Nations Development Fund (UNDP). The CDR focused on the role of the private sector in the Somali crises and how members could positively contribute to the transition process (Somali Business Council 2003). The members of the business community who participated in the July 21-22, 2014 meeting in Djibouti were all interested in influencing the forthcoming transitional government, particularly considering potential economic impacts. The pressure placed on Somali businesses by anti-terrorism legislation and actions by the United States was

9 Somalia (2001-2005) negotiation case information is from the BP project. 
a particular motivator for businessmen to find solutions that would satisfy the international actors and allow the Somali economy to function.

The Eldoret/Mbagathi process was the fifth Somali national peace negotiation since the fall of the Siad Barre regime in 1991. The Somali National Peace Conference lasted two years, and sought to create a federal and non-centralized state system. At the end of the process, the following resolutions were adopted: the Eldoret Declaration on Cessation of Hostilities, the Structures and Principles of the Somalia National Reconciliation Process, the Transitional Federal Charter, and the Transitional Federal Parliament including a 12\% gender quota for women. The Transitional Federal Parliament elected Abdulahi Yusuf, former leader of Puntland, as President in October 2004 with a five-year mandate (Interpeace 2009). However, the process was dogged by mismanagement, exclusion of key stakeholders, claims of corruption, and external interference from Ethiopia (International Crisis Group 2004). It was also highly driven by regional countries, while domestically Somali representation was fragmented between rival factions. The Leaders' Committee (the highest Somali decision-making body in the process) had veto power over decisions and oversaw the selection of delegates, turning the reconciliation process into a fight over power as they sought to stack the committees with members from their faction (Interpeace 2009).

Unlike in Kenya and El Salvador, the negotiation process was only partially successful in Somalia, despite the adoption of the above-mentioned agreements. The talks ended in March 2005 with a split occurring in the Transitional Federal Government over the issue of African Union peacekeepers (CRD 2006). Although the negotiation process had the objective of finding a political settlement to the ongoing conflict between the Transitional National Government in Mogadishu and the rival power in the country called the Somali Restoration and Reconciliation Council (SRRC), it failed to achieve that. These regimes were respectively supported by rival regional actors, Djibouti and Ethiopia. Attempts to find a political solution to the crisis were first initiated by Kenya's President Moi in December 2001 with representatives from both the Transitional National Government and the Somali Restoration and Reconciliation Council (SRRC) meeting in Nakuru, Kenya, (Interpeace 2009). Following the failure of this intervention, the Intergovernmental Authority on Development (IGAD) decided to launch another Somali peace process (Healy 2013). IGAD initiated the Somali peace process by recruiting President Moi at its annual summit in January 2002 to work with Ethiopia and Djibouti and bring the two conflict parties together (Healy 2013). The Eldoret/Mbagathi process represented the first concerted effort by Kenya, Ethiopia, and Djibouti to work together under the IGAD to solve Somalia's problems. After some delays, the Somali National 
Reconciliation Conference, led by Kenya with international backing, opened in Eldoret, Kenya in October 2002 (Healy 2013).

During the peace process, members of the Somali business community met on three occasions with political representatives from the organizing member states of Kenya, Djibouti, and Ethiopia. The business representatives also met with Kenya's Special Envoy to the Somalia peace process, mediator Bethuel Kiplagat (IRIN 2003). The 27-member multi-clan group from the Somali Business Council attended the peace talks where the head of the Council, Muhammad Jirde Husayn, expressed clearly that the group had been created "to see how best we can contribute to the reconciliation process" and that they "will support morally, materially and physically any new government that comes out of Nairobi" (IRIN 2003). The group also addressed the plenary of the Somali National Reconciliation Conference, pledging their commitment and support to the peace process (CRD \& wSP International 2004). However, negotiations dragged on for over two years with problems of corruption, mismanagement by the regional states, and ongoing tensions and conflict between delegates. Warlords and political leaders became the primary focus of negotiations, while non-armed civil society groups and organizations such as clan elders, members of diaspora, business community, and women not associated with warlord factions were marginalized.

Despite the efforts and the willingness of the Somali business community to help, the consultations between the Somali business community and foreign representatives and mediators at the Somali National Reconciliation Conference did not eventually have any considerable effect on the final adopted Transitional Charter. The consultations focused on the role of the private sector in the Somali crisis and how members could positively contribute to the transition process after the Kenya talks (Somali Business Council 2003). As a result of the consultations, a Peace and Reconciliation Committee was established by the Somalia Business Council to research and collect information on opportunities available for business members to support peace and reconciliation, and to encourage support among the greater Somali population (Somali Business Council 2003).

However, these consultations could not link the discussions taking place between business people attending the conference as delegates and those participating in the consultations. The consultations between the country organizers of the conference and representatives from the Somali business community did not receive any support from the Somali warlords and the political elite. Unlike in Kenya, in Somalia there were two fragmented political entities, and thus no single government that could capitalize on and harness the support given by the business to develop a strategy for national reconstruction. The political factions were opposed to the inclusion of civil society 
groups in the negotiations in general and consultations were held outside the process.

Furthermore, the SBC was mainly in diaspora and not adequately connected to local actors, especially the influential warlords and armed actors. Eventually a 23-member Arbitration Committee, consisting of five representatives from each of the major four clans and three from the minorities, was established to mediate disagreements. Clan elders were flown into Nairobi to nominate the delegates to the Transitional Federal Assembly. Between August and October, the essential parts of the conference, an adopted Transitional Charter and a selected Transitional Federal Parliament, were finalized without much input from business (Healy 2013).

In Kenya, similar to the Somalia case, there was a business community willing to play a constructive role in the negotiations, such as supporting the peace agreement, that ultimately was concluded through consultations. They supported the peace agreement that was concluded after consultations. The Kenyan Association of Manufacturers (KMA) was the organization of the entrepreneurs included in the negotiations through informal consultations with the African Union mandated mediation team comprised of Kofi Annan and Graca Machel. ${ }^{10}$ Like the SBC, KMA was also interested in an end to the violence in the country and an agreement that would create an environment conducive to business. The post-election violence in the country that occurred after the 2008 elections hurt the business interests, as was demonstrated during a workshop conducted to analyze the impact of the crisis on the economy (Kanyinga 2011). ${ }^{11}$ Business actors were already organized in Kenya, and were prepared to engage and be part of a negotiation process. They formulated recommendations to solve the crisis and conveyed them to the mediation team.

Despite the similarities in what motivated their inclusion and use of the consultation modality, business actors in Kenya managed to have a positive influence over the government and the negotiations. The consultations and recommendations of KMA had a substantial impact on the formulation of the negotiation agenda, helped mediators to put pressure on the parties, and shaped the agenda for implementation. The impact of the business groups on the negotiations was possible due to the strong engagement of the groups, as well as an openness of the meditation team to outside input from different segments of the society and their ability to communicate the interests of the civil society to convince the conflicting parties. Unlike the diaspora-based SBC in Somalia that was relatively disconnected from the local actors and closely

\footnotetext{
10 Kenya (2008) negotiation case information used in this article is from the BP project database.

11 Interview with Member of Mediation team October 2013 conducted by Thania Paffenholz.
} 
connected to elites, KMA was well-connected with political actors both locally in Kenya and internationally. They also had organic relations with other civil society actors. In fact, according to the mediation team, their recommendations were in line with the recommendations forwarded by other civil society actors included separately in the consultations, such as the Concerned Citizens for Peace and Kenyans for Peace, Justice, and Human Rights. Finally, unlike in Somalia where the negotiation process was seen as inefficient and mismanaged by regional countries bogged down in a rivalry, in Kenya the mediation team was highly effective in managing the negotiation process and strategically using the results of the consultations to not only shape the negotiation agenda but also to put pressure on the parties. Therefore, the well-intended efforts of business were carried into the negotiations successfully with the help of effective mediators.

\section{Discussion and Conclusion}

This article examined the types and forms of business sector inclusion in negotiations in terms of who from economic sector was included and through which modalities. A wide range of business actors are frequently included in peace and political transition negotiations through a variety of modalities. Consultation is the most common modality used in inclusion. Direct representation of business actors at the table may increase their influence over the negotiations as opposed to other indirect modalities. However, consultations can also be influential if they are designed to be part of an effective mediation process and if an effective transfer channel exists, such as in Kenya. Regardless of the modality used, most of the time business inclusion takes place within a broader civil society inclusion process. Occasionally, business has also been included in negotiations as a stand-alone actor especially when it is already a key player in the economic and political landscape.

The findings from the four case studies reinforce some of the arguments posited by the existing literature regarding the conditions under which business engages with peace efforts successfully. Killick and Gunduz (2005) identified the following conditions for business engagement: a) business having an interest in peace, b) existence of an influential and diverse business sector, c) independent and positively perceived private sector, and d) individual business leaders who are prepared to take a lead in the peace process. Different considerations may motivate business actors to become interested in peace; for example, they may be motivated by an awareness of the costs of the conflict or by potential gains if conflict ends. 
All of these conditions were lacking in the Guatemala case. CACIF thought that the socio-economic reforms for a more inclusive system were a threat to their interests. Independence and diversity among business actors were also lacking in Guatemala. On the other hand, the first two conditions exist in the El Salvador and Kenya cases, while the first and the fourth exist in Somalia case but not the others. Considering the outcomes of these cases, future research should test with large number of observations to corroborate whether the first two conditions weigh more heavily than the other two for business to have influence. However, the case studies examined in this article point to another critical dimension, beyond the above listed conditions: the quality of business engagement with peace efforts. The El Salvador and Guatemala cases are very informative in helping us think to what extent the engagement of business elite in a peace process is moving the transformative inclusion agenda forward. ${ }^{12}$

One of the most important take-aways from this article is that, as with the inclusion of women, ${ }^{13}$ it is essential to consider the quality of inclusion rather than just influence. Business actors may even be more influential than other actors because they have economic power that they can use to spoil a process or to introduce the essential resources for the implementation of an agreement. Hence, they are often included, but the extent to which their inclusion helps the country move in the direction of accomplishing inclusive economic and political institutions and addressing the root causes of the conflict varies. Like in Guatemala, and to some extent in El Salvador, business inclusion may take place at the expense of achieving a just and inclusive society. While their inclusion in negotiations may facilitate an elite bargain in the short run necessary to achieve an agreement, it may restrict broader societal inclusion in the long run.

This article posits that the more benefiting and dependent the business sector is on cronyism, corruption, and an extractive economic system in a country, the more negatively their inclusion will be viewed by the public or other societal actors in a peace process. In addition, when business actors are benefiting from an extractive or non-inclusive economic and political system, it is less likely that they will support a peace process that will transform the existing structure of society towards an inclusive one. In this context, business may be more influential over the government and in politics, but at the same time disconnected and disliked by the "excluded" parties at the societal level. This

12 I use the term transformative inclusion to refer to the ultimate goal of achieving inclusive economic and political institutions in a society.

13 A similar conclusion is drawn on women inclusion, see Paffenholz et al. 2016. 
was the case in Guatemala and El Salvador, where business was seen hostile to the demands for economic, political, and cultural inclusion of the indigenous Mayan population by civil society and left leaning communities. Negotiations for peace are perceived as a threat overthrowing the old institutions from which they benefit and to establish new institutions that constrain their economic and political control. If the agreement envisages a transition to an inclusive society and socio-economic reforms alluding to the redistribution of wealth, business actors may prevent the implementation of that agreement, as was the case in Guatemala. Alternatively, such as in the case of El Salvador, they can become supportive and compromise if they are given guarantees in the process to keep their interests and power intact, and if given incentives to gain from the new system including the promotion of new ways of doing business with the USAID-supported projects. Adopting these new ways of business required the establishment of peace in the country, but not necessarily one that transforms the conditions that create the root causes of the conflict.

El Salvador is an important case as it illustrates the dilemma posed by most inclusive peace negotiations. Peace negotiations must strike a balance between reconciling elites' interests and at the same time addressing the demands of broader societal groups, especially those that have been excluded for many years (Bell \& Pospisil 2017). The needs of those representing economically excluded classes that have borne structural inequalities and developed grievances, as well as those representing the economically privileged sub-set that contributed to the root causes of the conflict, must be reconciled in the negotiations simultaneously. If only one is included in the negotiations, while the other is excluded, the implementation of the agreement may suffer. This was the case in Guatemala with CACIF's self-exclusion from the ASC and other societal actors' inclusion and influence over the peace agreement through ASC. Inclusion of other societal actors in the negotiations did not prevent CACIF from creating problems in the implementation later in the process, especially given their continued economic and political power.

Lastly, organizational capabilities and pre-existing networks of business actors are other important conditions that may facilitate an effective business inclusion. Their success is likely to increase, such as in Kenya and El Salvador, when they are well-connected to not only local political actors but also wellnetworked with other actors in the civil society. One important facilitating condition for business actors is that, unlike some other segments of civil society, they are usually among the most organized, networked, and professional in a society. In most cases, regardless of whether there is a negotiation process or not, some sort of business network and organizational capacity already exists. 
This pre-existing network can become useful at the time of negotiations, if business is motivated and chooses to get involved to support peace efforts. This was true for the Somalia Business Council and ANEP. Unlike some other civil society actors such as women, they don't need to organize before being included in the process. Even in a country where state authority is severely challenged and incapacitated, like Somalia, there was an organized business group, even if it was based in Dubai, that could become involved and support the negotiation process in addition to organizing the local business actors.

\section{References}

Acemoglu, Daron and J. Robinson (2013). Why Nations Fail: The Origins of Power, Prosperity, and Poverty. New York: Random House Publishers.

Bell, Christine (2015). "Text and Context: Evaluating Peace Agreements for their Gender Perspective." Political Settlements Research Program. Edinburgh: University of Edinburgh.

Bell, Christine and J. Pospisil (2017). "Navigating Inclusion in Transitions from Conflict: The Formalized Political Unsettlement." Journal of International Development 29, 5: 576-593.

Collier, Paul (2000). Economic Causes of Civil Conflict and their Implications for Policy. Washington, DC: World Bank.

Collier, Paul and Anke Hoeffler (200o). "Greed and Grievance in Civil War," The World Bank Policy Research Working Paper 2355.

Collier, Paul and Anke Hoeffler (2002). "Aid, policy and peace: reducing the risks of civil conflict." Defence and Peace Economics 13, 6: 435-450.

Center for Research and Dialogue (2006). "Dialogue for Peace." At: http://crdsomalia .org/.

CRD \& WSP International (2004). "High-Level Dialogue with the Somali Business Community Djibouti 21st-22nd July 2004: A Summary Report." At: http://www .somali-jna.org/downloads/High\%2oLevel\%2oDialogue\%2owith\%2oSomali\%20 Business\%2oCommunity\%2oSummary\%2oR.pdf.

Forrer, John, Timothy Fort, and Raymond Gilpin (2012). "How Business Can Foster Peace?" Special Report, Washington, DC: United States Institute of Peace.

Galtung, Johan (1969). “Violence, Peace, and Peace Research." Journal of Peace Research 6, 3: 167-191.

Grizelj, Irena (2017). "The Youth Space of Dialogue and Mediation in Myanmar." Berlin: Berghof Foundation.

Healy, Sally (2013). "IGAD and Regional Security in the Horn." In James J. Hentz, editor, Routledge Handbook of African Security. London: Routledge. 
International Crisis Group (2004). "Biting the Somali Bullet." ICG Africa Briefing No. 79, May 4.

Interpeace (2009). in Pat Johnson, editor, A History of Mediation in Somalia since 1988. At: www.crdsomalia.org.

IRIN (2003). "Somalia: Business community to support all-inclusive government." IRIN. At http://www.irinnews.org/report/43968/somalia-business-community-to -support-all-inclusive-government.

Kanyinga, K (2011). "Stopping a Conflagration: The Response of Kenyan Civil Society to the Post-2007 Election Violence." Politikon 38, 1: 85-109.

Killick, Nick and Canan Gunduz (2005). "The Peacebuilding Potential of Local Businesses," in Paul van Tongeren, Malin Brenk, Marte Hellema, and Juliette Verhoeven, editors, People Building Peace II: Successful Stories of Civil Society. Boulder, CO: Lynne Rienner Publishers.

Killick, Nick, VS Srikantha, and Canan Gunduz (2005). The Role of Local Business in Peacebuilding. Berlin: Berghof Research Center for Constructive Conflict Management.

Levinger, Matthew (2013). Conflict Analysis: Understanding Causes, Unlocking Solutions. Washington, DC: United States Institute of Peace Press.

Nelson, Jane (2000). The Business of Peace. Report by the Prince of Wales Business Leaders Forum, International Alert, and Council on Economic Priorities.

Nilsson, Desire (2012). "Anchoring the Peace: Civil Society Actors in Peace Accords and Durable Peace." International Interactions 38, 2: 243-266.

Paffenholz, Thania (2014). "Civil Society and Peace Negotiations: Beyond the InclusionExclusion Dichotomy.” Negotiation Journal 30, 1: 69-91.

Paffenholz, Thania, Nick Ross, Steven Dixon, Anna-Lena Schluchter and Jacqui True (2016). "Making Women Count - Not Just Counting Women: Assessing Women's Inclusion and Influence on Peace Negotiations." Geneva: Inclusive Peace and Transition Initiative (The Graduate Institute of International and Development Studies) and UN Women.

Rettberg, Angelika (2006). Local Business, Local Peace: The Peacebuilding Potential for the Domestic Private Sector - Case Study: El Salvador. International Alert.

Salvesen, Hilde (2002). Guatemala: Five Years after the Peace Accords. The Challenges of Implementing Peace. Oslo: PRIO.

Somali Business Council (2013). "Statement on the Promotion of Peace and Reconciliation in Somalia." At http://www.banadir.com/somali.htm.shtml.

Stewart, Frances and G. Brown (2007). "Motivations for Conflict: Groups and Individuals," in Chester Crocker, Fen Osler Hampson, and Pamela Aall, editors, Leashing the Dogs of War: Conflict Management in a Divided World. Washington, DC: Usip Press.

Swisspeace (2016). Proceso de Paz en Guatemala. Guatemala: Centro de Estudios de Guatemala. 